\title{
Characterization of Pigments and Binders in Mural Painting Fragments from Bezeklik, China
}

\author{
M. R. Singh ${ }^{\mathrm{a}, *}$, B. R. Mani $^{\mathrm{b}}$ \\ a National Museum Institute, Department of Conservation, Janpath, New Delhi-110011 \\ b National Museum Insitute, Janpath, New Delhi-110011.
}

(Received 27 March 2019)

\begin{abstract}
This paper reports the result of identification of pigments and binders used in wall painting fragments in Bezeklik Grottoes (5th-14th CE), now housed in the Central Asian collection of National Museum, New Delhi. The tiny pigment samples (100-200 $\mu \mathrm{m}$ in size) extracted from some of the artworks have been analyzed to gain information on the art materials and painting techniques. Analysis by Micro-Raman spectroscopy, complemented with Scanning Electron Microscopy -Energy Dispersive X-ray Spectroscopy (SEM-EDX) and Wavelength Dispersive X-ray fluorescence (WD-XRF) allowed identification of lamp black, azurite, atacamite, gypsum, red lead and haematite as pigments and gypsum as a ground layer. The unsaturated and saturated fatty acids and terpineol extracted from the micro sample were identified as organic binders by Gas Chromatography-Mass Spectrophotometer (GC-MS) analysis. The multi-analytical studies have allowed material characterization in terms of the elemental composition of pigments.
\end{abstract}

Key words: Azurite, Bezeklik Grottoes, GC-MS, Micro-Raman Spectroscopy, Pigments, WD-XRF.

\section{Introduction}

The investigations of decorative artifacts and wall paintings are challenging and important to understand the objects' history, ancient technology, conservation, restoration, dating and authenticity of the artworks. One of the tasks faced by the art conservators is to select the right kind of materials for conservation interventions that demand proper investigations of the original works of art. It has been observed that several materials used in conservation are in no way related to original one and also some-

DOI: $10.16943 / \mathrm{ijhs} / 2019 / \mathrm{v} 54 \mathrm{i} 3 / 49745$

*Corresponding author: m_singh_asi@yahoo.com times cause damage to artworks (Pérez-Alonso, Castro and Madariaga, 2006; Burgio, Clark, Rosser-Owen, 2007). Most of the wall paintings in India have been executed with inorganic pigments either pure or mixed which were added in binding media mainly identified as animal glue in tempera technique (Sharma, 2007, pp. 102-106). The conservation of mural art is a very delicate operation that demands the utmost dexterity and knowledge of each constituent of the materials and painting technique (Mora, Mora, Philippot, 1984). In many instances, it has been observed that certain materials used in past conservation are not at all suited for the original objects (Burgio, Clark, Rosser-Owen, 2007). Several investigative studies have been carried in the past to document information about 
the pigments (Burgio,Clark, Rosser-Owen, 2007; Colomban, 2003; Ernst, 2010; Correia et al. 2007; Frausto-Reyes et al. 2009), the authenticity of the work of art (Clark, 2007) and environmental degradation product (Smith and Clark, 2002). Many of these studies have been carried in-situ in non-invasive techniques (Burgio,Clark, RosserOwen, 2007; Colomban, 2003; Ernst, 2010; Correia et al. 2007; Frausto-Reyes et al., 2009) while many others have been performed on pigment fragments removed from actual works of art (Correia et al., 2007; Frausto-Reyes et al. 2009; Smith and Clark, 2002; Clark and Curri, 1998; Edwards et al. 2003). Raman spectra of a large number of natural and synthetic pigments have been studied and the results reported in the form of spectroscopic libraries (Burgio and Clark, 2001; Bell, Clark and Gibbs, 1997). In the last two decades Raman spectroscopy has increasingly been applied to study historical pigment (Edwards et al. 2003; Coupry et al. 1994; David et al. 2003; Best et al. 1994; Schmidt et al. 2016; Zuo et al. 2003) because the technique requires very minute quantity of sample and is non-destructive. Raman spectroscopy has a weak response to water molecules and therefore no desiccation of samples is required. Extensive Raman spectroscopic studies on pigments have been published from many countries (Burgio,Clark, Rosser-Owen, 2007; Colomban, 2003; Edwards et al. 2003; Burrafato et al. 2004; Tomasini et al. 2012; Zumbuehl et al. 2009), but report on pigment analysis from India and China are rather limited compared to numbers of historical decorative arts. It is well known that India and China are the home of several ancient civilizations from pre-historic to middle age that has left its imprints in the form of works of arts and paintings. In India, the pigments of famous Ajanta caves have recently been investigated by multi-analytical techniques (Singh, 2011). The pre-historic world heritage site pigments of Bhimbetka were analyzed with portable Raman spectroscopy and the fragments also investigated in the laboratory (Ravindran et al. 2012). A few selected Indian miniature paintings of medieval period have been studied and pigments identified (Ravindran et al., 2010).

Organic additives (biopolymers) derived from plant and animals are generally used as binder and waterproofing agent for tempera paintings. These organic additives not only decrease the cracking but also increase overall binding capacity of pigment layer. The majority of adhesive added are of natural origin, animal origin (beeswax) or plant origin (soyabean, rapeseeds, calabar bean). Organic materials generally require special care and attention in the conservation of paintings, because of their relatively increased tendency with reference to the inorganic constituents to go through transformation, degradation and oxidation processes (Grattan, 1979). In fact, at a macroscopic level the paint layers may exhibit cracking, yellowing, darkening, and loss of cohesion and stability due to the degradation of binding media. Drying oils (walnut, linseed and poppy seed oils), plant resins (e.g., sandarac, colophony, mastic, dammar), egg (yolk, whole, or glair), animal glue, casein or milk, animal resins (shellac), and waxes (beeswax) are the most common organic materials historically used in wall paintings as binders. These materials are complex mixtures of triglycerides, organic species, consisting of proteins, terpenes compounds, sterols, esters, hydrocarbons, free acids, alcohols, etc. (Mills and White, 1994). The physical properties and chemical composition of organic binders are considerably affected by aging and environment (Sturman, 1980). These, Organic materials in paintings play an important role as constituents of the preparation and priming layers to reduce their water permeability and porosity that also enhance the smoothness of the surface, and avoid the penetration of fluid binding media from paint layers (Cennini, 2003).

In the present study, we report the analysis of pigments extracted from the fragments of painted plasters of Bezeklik, China (5th-14th CE). The analytical investigations were performed by micro-Raman spectroscopy and the data supported by WD-XRF and SEM-EDX measurements. The organic binding media mixed in the pigment was also analyzed through GC-MS analysis.

The Buddhist cave grottoes of Bezeklik (5th -14th CE) were a Buddhist Centre of the ancient city of Gaochang in the Uyghur region, about 50 kilometers east of Turpan (Figure 1). The caves were excavated under the Gaochang kingdom (499-640) and served as royal Buddhist temple of Uyghur Gaochang kingdom. The royal family moved east to Yongchang, Gansu province in the late 13th century, which led to the decline of the status of Bezeklik caves and its condition dilapidated during the 15th century, with the spread of Islam from Mongolian expeditions in the region (Wang, 2016, p. 297).

The Bezeklik caves were profusely decorated with murals and were rich repositories of manuscripts, paintings, 


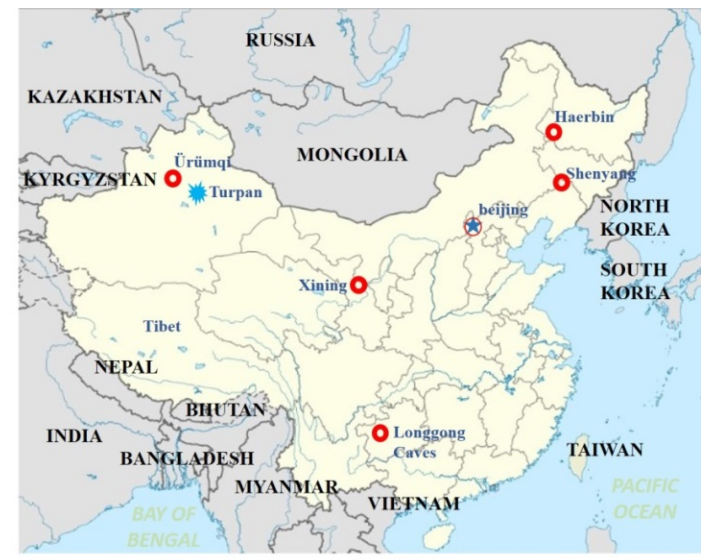

Figure 1 Map showing location of Bezeklik, Thousand Buddha Caves, Trupan, China

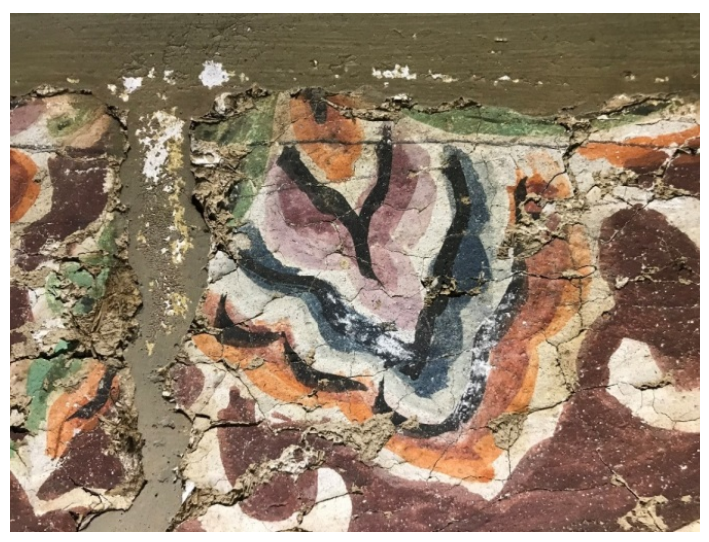

Figure 2 The general view of the painted fragment of Bezeklik, China. and other objects. In the late nineteenth century and early twentieth century, a series of explorers and archeologists uncovered and excavated the site. Many manuscripts, artifacts, sculptures, and wall painting fragments were removed from the temples and sent to Germany, Japan, Russia, UK, and India. Sir Aurel Stein removed a significant number of fragments of painted plaster, embedded them in Plaster of Paris, anchored with iron hooks and transported to India during his three expeditions between 1900 and1916 and they are now one of the rare collections of central Asian antiquities presently housed in National Museum, New Delhi. The fragments of paintings have much deteriorated during the detachment from cave walls, natural aging of painted plaster, transportation from China to India, inappropriate storage condition and during past conservation. Conservation works in the form of filling the gaps with Plaster of Paris and application of aqueous dispersion of polyvinyl acetate (PVA) have been carried for the fragments in the past (Figure 2).

\section{Painting technique at Bezeklik}

The wall paintings of Bezeklik have been executed on earthen plaster ground, sourced from locally available materials. Preliminary investigations under magnifying lens show an inner rough earthen plaster layer containing $80 \%$ of silt, $20 \%$ of sand and devoid of any clay size particles (Dighe et al., 2018). To increase the cohesiveness paddy stems and husk have been incorporated as re-enforcement to impart strength and flexibility to the plaster. On the earthen plaster layer, a thin white gypsum layer has been applied on which the paintings executed (Figure 3). The colors used in wall paintings of Bezeklik are mainly red, white, green, blue, orange, black and red ochre colors that were subjected to analysis in this work. We have not observed any microbial activity or graying of pigments during investigative studies as reported for the fragments of central Asia housed in Berlin Museum (Ellen and Simon, 2015, pp. 45-53).

\section{Materials and methods}

For investigation few tiny pigment samples (100-200 $\mu \mathrm{m}$ in size) of seven different colors (white, black, red, blue, 


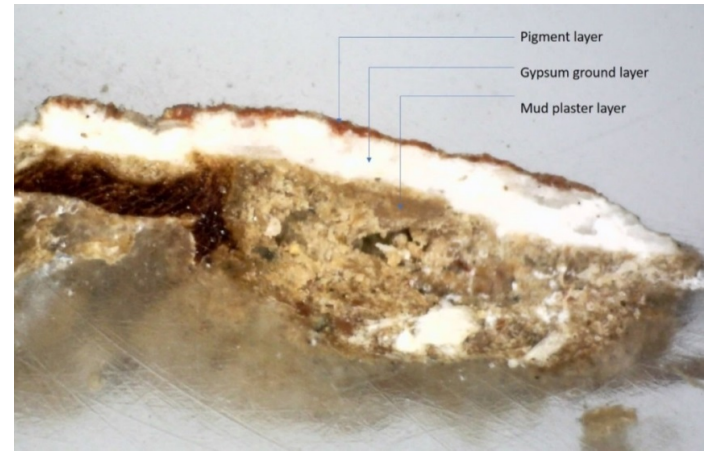

Figure 3 Stratigraphy of the painted plaster of Bezeklik, China.

green, orange, ochre) were extricated from the loosely attached fragmented portions of painted plasters. The samples were studied in the laboratory using Renishaw In Via micro-Raman Spectrometer employing a $50 X$ objective and $514 \mathrm{~nm}$ and $785 \mathrm{~nm}$ laser excitation. Around 1-micron area of the sample was targeted, and spectra recorded with CCD detector. The resolution of the instrument was $1.5 \mathrm{~cm}^{-1}$. We have used wire 3.2 software for baseline correction and smoothing of the spectra for Raman images in this work.

The composition analysis of the samples was also performed under FEG-SEM, supra 55 Zeiss Scanning Electron Microscope coupled with $10 \mathrm{~mm}$ 2SDD EDS detector (Oxford Instruments). The elemental composition of the pigment samples was measured with Rigaku supermini200 high powder sequential wavelength dispersive X-ray fluorescence (WD-XRF). The results of our analytical investigations are presented in this work.

The binding media of the pigment was analyzed under Gas Chromatography coupled with Mass Spectroscopy. The selected homogenized sample (25 mg) was dissolved in $10 \mathrm{ml}$ of methanol (HPLC grade) Sigma-Aldrich at 27 ${ }^{\circ} \mathrm{C}$ for 24 hours. The sample was then filtered out using Whatman filter paper (Grade 1). The filtered sample was analyzed using GCMS-QP2010 Ultra instrument (Shimadzu, Kyoto, Japan), equipped with an AOC-5000 plus autosampler, an OPTIC-4 injection system and a nonpolar Restek Rxi-5 Sil MS column (5\% diphenyl- 95\% dimethylpolysiloxane, 30 meters x 0.25-millimeter i.d., x 0.25-micron film thickness). Helium (99.999\% Linde) was used as the carrier gas with a flow rate of 0.9 millimeters per minute. Split injection mode at $260^{\circ} \mathrm{C}$ with split ratio of 10.0 and sample volume $1.5 \mu \mathrm{l}$ was employed. The column temperature was held at $60^{\circ} \mathrm{C}$ for 2 minutes, ramped at $10{ }^{\circ} \mathrm{C}$ per minute to $280{ }^{\circ} \mathrm{C}$ for 18 minutes (Total run time was 55 minutes). The mass spectrometer was operated with electron impact ionization $(70 \mathrm{eV})$ and in the SCAN monitoring.

Interpretation of GC-MS chromatogram was conducted using the database of National Institute Standard and Technology (NIST) and Wiley having more than 62000 patterns. The spectrum of the unknown component was compared with the spectrum of the known components stored in either of the libraries.

\section{Results and discussion}

\subsection{Raman spectroscopy, SEM-EDX, and WD-XRF of pigments}

\subsubsection{White pigment}

For Raman spectroscopy, the white area of the pigment was targeted, and the spectra recorded in the wave number regions 100 to $2000 \mathrm{~cm}^{-1}$ under $785 \mathrm{~nm}$ laser excitation (Figure 4). The peaks at 178, 410, 492, 615, 665, 1002 and $1133 \mathrm{~cm}^{-1}$ can be assigned to gypsum. The presence of gypsum has been inferred from its main band at $1002 \mathrm{~cm}^{-1}$ ( $\nu 1$ symmetric stretching of $\mathrm{SO}_{4}^{2-}$ - tetrahedral) and minor bands at 410 and $492 \mathrm{~cm}^{-1}$ ( $\nu 2$ symmetric stretching of $\mathrm{SO}_{4}^{2-}$ ), 615 and $665 \mathrm{~cm}^{-1}(\nu 4$ asymmetric bending of $\mathrm{SO}_{4}^{2-}$ ) and $1133 \mathrm{~cm}^{-1}(\nu 3$ asymmetric stretching) (Jehlička et al. 2009; Antunes et al. 2014; PrietoTaboada et al. 2014; Marszałek, 2016). The band positions of gypsum obtained in this study slightly vary from the published literature $(181,415,493,617,670,1008$, $1134 \mathrm{~cm}^{-1}$ ) (Bell, Clark, Gibbs, 1997; Prieto-Taboada et al. 2014; Caggiani, Cosentino, Mangone, 2016) which is generally be attributed to the spectral resolution of the instrument. The occurrence of gypsum as a white pigment has also been noted in other studies on central Asian wall paintings (Schmidt et al. 1997; Guoxin, Jiangquan, Huaiwan, 1997). The whitewash stratigraphy layer also gave similar spectra of gypsum under Raman spectroscopy.

All the pigments (except black) were also scanned under SEM-EDX and the data were taken on 50-60-micron sample area exposed for this purpose. The quantitative EDX data of the pigments are shown in Table 1 with the elements detected. From the EDX data of white spot, it 


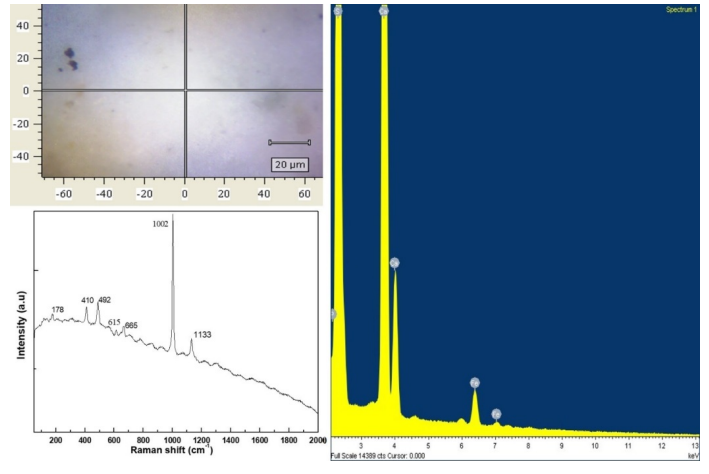

Figure 4 White colour targeted area with Raman spectra under 785nm laser and its EDX spectra.

is observed that there is a high content of calcium, sulfur, and oxygen pointing towards the use of gypsum as a white pigment. The presence of traces of iron in the EDX spectra of white pigment (Figure 4) may be due to the migration of ion from the surrounding red color pigments.

All the pigments (except black) were also observed under highly sensitive WD-XRF and data presented in Table 2. The WD-XRF of white pigment showed a typical calcium sulfate composition with the calcium fluorescence ( $\mathrm{Ca} \mathrm{K} \alpha$ lime) and Sulphur ( $\mathrm{k} \alpha$ line) as the most intense peaks and the least intense peak of $\mathrm{Fe}$ and $\mathrm{Pb}$ probably due to the migration of ions from the surrounding red color. The data confirms the use of gypsum as a white pigment in accordance with Raman spectra results.

\subsubsection{Black pigment}

From the prehistoric times, carbon black has been the most important black pigments produced by incomplete combustion of lamp oil (lamp black), bone (bone black), ivory (ivory black) and plants (charcoal black) etc. Previous studies on black pigments using Raman spectroscopy have suggested that carbon-based reference pigments show a range of Raman band positions (Tomasini et al. 2012; Coccato et al. 2015) depending on the source and composition of black pigments. The G-band of black pigment showed values from $1578-1603 \mathrm{~cm}^{-1}$ whereas the D band position values were from $1345-1394 \mathrm{~cm}^{-1}$ (Tomasini et al. 2012).

The Raman spectra of black pigment under $785 \mathrm{~nm}$ laser excitation resulted in characteristic bands at 1314 $\mathrm{cm}^{-1}$ (D1 band) and $1593 \mathrm{~cm}^{-1}$ (G band) showing carbon

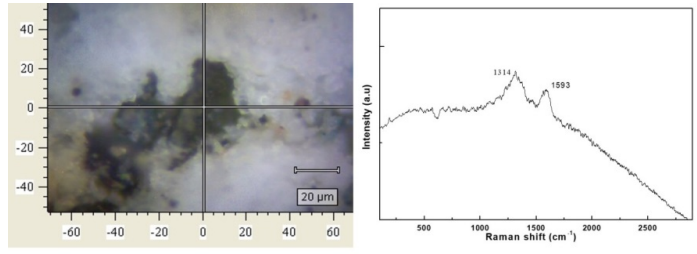

Figure 5 Black color targeted area with Raman spectra under $785 \mathrm{~nm}$ laser.

as the principal constituents of the black pigment (Figure 5). The $\mathrm{G}$ band is assigned to the in-plane stretching vibration of aromatic ring $\mathrm{C}-\mathrm{C}$ band ( $E_{2} g_{2}$ mode) whereas the $\mathrm{D}$ band, known as discoloring band, occurs as a result of in-plane defects and due to presence of heteroatoms ( $A_{1}$ g mode) (Coccato et al., 2015; van der Weerd et al., 2004). The samples show $D$ and $G$ broad bands characteristic of amorphous carbon. The relatively broad bands suggest the low degree of crystallinity of the black pigments.

\subsubsection{Red pigment}

The red area in the sample was targeted under $514 \mathrm{~nm}$ laser excitation and the spectra were taken (Figure 6). The peak obtained at $545 \mathrm{~cm}^{-1}$ is the very strong peak of red lead. The peak at $475 \mathrm{~cm}^{-1}$ may be assigned to the very weak peak of red lead. Originally, the peaks at 480 and $548 \mathrm{~cm}^{-1}$ were assigned the most important peaks of red lead but there is a slight shift in the peaks due to the spectral resolution of the instrument. From the Raman spectra of the sample, it is elucidated that white gypsum layer has isolated inclusion of red lead.

The red pigment was also scanned under a scanning electron microscope and EDX data taken, Table 1. It is seen from the EDX data that the high concentration of lead (12.75 wt. \%) is present in the measured spots along with traces of iron and copper pointing use of red lead as a colorant. The EDX also showed the major concentration of calcium, sulfur, and oxygen from the gypsum base. The high percentage of oxygen also originates from the red lead composition (Figure 6).

From the WD-XRF of the red pigments (Table 2), the high percentage of lead (25.10 wt. \%) was detected in the sample. The pigment also contains traces of $\mathrm{Fe}$ and $\mathrm{Cu}$ 
Table 1 EDX data of the various pigments of Bezeklik, China (Weight \%).

\begin{tabular}{|c|c|c|c|c|c|}
\hline Element & $\begin{array}{c}\text { White } \\
\text { pigment }\end{array}$ & $\begin{array}{c}\text { Red } \\
\text { Pigment }\end{array}$ & $\begin{array}{c}\text { Blue } \\
\text { pigment }\end{array}$ & $\begin{array}{c}\text { Green } \\
\text { pigment }\end{array}$ & $\begin{array}{c}\text { Orange } \\
\text { pigment }\end{array}$ \\
\hline $\mathrm{O}$ & 52.87 & 41.90 & 46.78 & 41.46 & 46.11 \\
\hline $\mathrm{C}$ & - & 10.14 & - & - & - \\
\hline $\mathrm{A} 1$ & 0.17 & 0.18 & 0.25 & 0.79 & 0.35 \\
\hline $\mathrm{Ca}$ & 24.34 & 20.00 & 28.32 & 11.29 & 18.21 \\
\hline $\mathrm{Fe}$ & 1.95 & 0.20 & 0.23 & 0.49 & 0.25 \\
\hline $\mathrm{Si}$ & 0.41 & 0.51 & 1.0 & 1.80 & 0.97 \\
\hline $\mathrm{S}$ & 19.98 & 13.99 & 22.70 & 9.86 & 14.07 \\
\hline $\mathrm{Cu}$ & - & 0.33 & 0.49 & 25.73 & - \\
\hline $\mathrm{Pb}$ & - & 12.75 & - & - & 19.80 \\
\hline $\mathrm{Na}$ & - & - & - & - & 0.24 \\
\hline $\mathrm{Mg}$ & - & - & - & 0.48 & - \\
\hline $\mathrm{C} 1$ & - & - & - & 8.11 & - \\
\hline $\mathrm{P}$ & 0.28 & - & 0.31 & - & - \\
\hline $\mathrm{Mn}$ & - & - & 0.9 & - & - \\
\hline
\end{tabular}

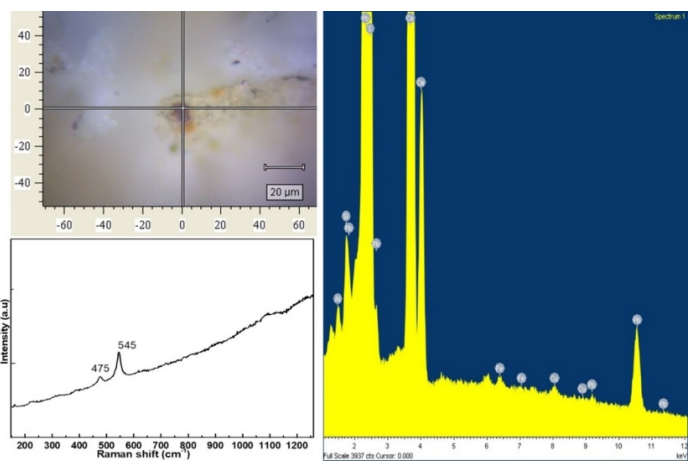

Figure 6 Red color targeted area with Raman spectra under $514 \mathrm{~nm}$ laser and its EDX spectra. probably added to obtain the desired hue. The conclusion of our SEM-EDX and WD-XRF analysis is compatible with the Raman spectra of the sample indicating the use of red lead as a pigment in Bezeklik artworks (Veiga et al. 2004).

\subsubsection{Blue pigment}

The Raman spectra of blue pigment under $514 \mathrm{~nm}$ laser excitation indicate the presence of Azurite $\left[\mathrm{Cu}_{3}\left(\mathrm{CO}_{3}\right)_{2}\right.$ $(\mathrm{OH})_{2}$ ], a monoclinic hydroxycarbonate of copper. The characteristic Raman bands appear at 136, 175, 248, 330, 400, 764, 836, 1094, 1436 and $1578 \mathrm{~cm}^{-1}$ (Figure 7). The azurite contains modes of three separate vibration group: $\mathrm{OH} . \mathrm{CO}_{3}$ and $\mathrm{Cu}-\mathrm{O}$ and is characterized by several bands that cover the spectral range up to $1600 \mathrm{~cm}^{-1}$. The bands observed up to $600 \mathrm{~cm}^{-1}$ are assigned to vibrations of $\mathrm{Cu}$ $O$ group and those observed up to $1600 \mathrm{~cm}^{-1}$ are assigned to $\mathrm{CO}_{3}$ complex (Frost et al. 2002; Mattei et al. 2008). Azurite has a characteristic intense band at $400 \mathrm{~cm}^{-1}$, which represent $\mathrm{CuO}$ stretching, bands at 764, 836, 1094, 1436 and $1578 \mathrm{~cm}^{-1}$ are due to $\nu 4$ asymmetric $\mathrm{CO}_{3}$ bending, $v 2$ symmetric $\mathrm{CO}_{3}$ bending, $v 1 \mathrm{CO}_{3}$ symmetric stretching, $v 3$ asymmetric $\mathrm{CO}_{3}$ stretching and $\mathrm{OH}$ bending mode, respectively (Frost et al. 2002; Mattei et al. 2008). Sev- 
Table 2 WD-XRF data of pigments of Bezeklik, China (Weight \%).

\begin{tabular}{|c|c|c|c|c|c|c|}
\hline Component & $\begin{array}{c}\text { White } \\
\text { pigment }\end{array}$ & $\begin{array}{c}\text { Red } \\
\text { Pigment }\end{array}$ & $\begin{array}{c}\text { Blue } \\
\text { pigment }\end{array}$ & $\begin{array}{c}\text { Green } \\
\text { pigment }\end{array}$ & $\begin{array}{c}\text { Orange } \\
\text { pigment }\end{array}$ & $\begin{array}{c}\text { Red Ochre } \\
\text { pigment }\end{array}$ \\
\hline $\mathrm{A} 1$ & 1.29 & 1.41 & 1.51 & 1.31 & 0.67 & 1.7 \\
\hline $\mathrm{Mg}$ & - & 0.141 & 0.06 & 0.14 & - & 0.17 \\
\hline $\mathrm{Si}$ & 4.11 & 4.29 & 4.24 & 3.89 & 2.22 & 5.84 \\
\hline $\mathrm{P}$ & - & - & - & - & - & 0.08 \\
\hline $\mathrm{S}$ & 21.3 & 19.4 & 16.1 & 11.5 & 13.9 & 10.5 \\
\hline $\mathrm{C} 1$ & 0.15 & 0.85 & 1.51 & 8.45 & 0.86 & 0.08 \\
\hline $\mathrm{K}$ & 1.05 & 1.08 & 1.96 & 0.67 & 0.75 & 0.79 \\
\hline $\mathrm{Ca}$ & 68.9 & 46.2 & 31.2 & 22.5 & 34.8 & 16.8 \\
\hline $\mathrm{Ti}$ & - & - & - & - & - & 0.26 \\
\hline $\mathrm{Cr}$ & 0.79 & 0.06 & 0.14 & 0.1 & 0.05 & 0.02 \\
\hline $\mathrm{Fe}$ & 1.27 & 1.12 & 0.63 & 0.71 & 0.05 & 62.9 \\
\hline $\mathrm{Mn}$ & - & - & - & - & - & 0.43 \\
\hline $\mathrm{Cu}$ & - & 0.35 & 41.3 & 49.5 & - & - \\
\hline $\mathrm{Zn}$ & - & - & 0.28 & - & - & - \\
\hline $\mathrm{Pb}$ & 1.17 & 25.1 & 1.04 & 1.23 & 46.7 & 0.47 \\
\hline
\end{tabular}

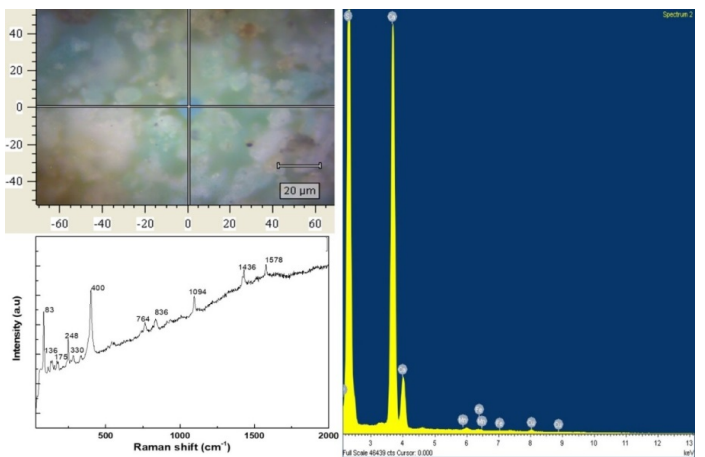

Figure 7 Blue color targeted area with Raman spectra under 514 nm laser and its EDX spectra.

eral studies on wall paintings of central Asian regions suggest extensive use of azurite as a blue pigment (Mazzeo et al. 2010; Wainwright et al. 1997, pp. 334-340; Zuixiong, 2010).

The blue pigment was scanned under a scanning electron microscope and EDX data taken, Table 2. From the EDX spectra, it is observed that the sample possesses a high content of copper to impart blue coloration along with traces of iron (Figure 7). From WD-XRF data (Ta- ble 2) it is observed that the sample contains high quantity of copper (41.3 wt. \%) to impart blue coloration along with traces of iron and lead probably mixed to obtain the desired hue.

\subsubsection{Green pigment}

The Raman spectra of green pigment were obtained under $514 \mathrm{~nm}$ laser excitation and the characteristic Raman bands confirm the presence of Atacamite $\left[\mathrm{Cu}_{2}\right.$ $\left.\mathrm{Cl}(\mathrm{OH})_{3}\right]$ a basic copper II chloride (Figure 8). Atacamite is a corrosion product of copper but has been extensively used as coloring agent in paint, particularly wall paintings (Mazzeo et al. 2010, pp. 275-85; Zuixiong, 2010; Naumova and Pisareva, 1994). The Raman spectra of atacamite show three most intense bands at around 513, 821 and $912 \mathrm{~cm}^{-1}$. Bands of much lower intensity are observed at 120,149, 359 and $976 \mathrm{~cm}^{-1}$. In the Raman Spectrum, bands less than $500 \mathrm{~cm}^{-1}$ indicate $\mathrm{Cu}-\mathrm{Cl}$ stretching vibrations, the $\mathrm{Cu}-\mathrm{O}$ vibrations occur around $513 \mathrm{~cm}^{-1}$ and hydroxy/ deformation modes are observed at 976, 912 and $821 \mathrm{~cm}^{-1}$ (with a shoulder around $\left.827 \mathrm{~cm}^{-1}\right)(48,49)$. Raman band is also observed at around $149 \mathrm{~cm}^{-1}$, which is attributed to the $\mathrm{O}-\mathrm{Cu}-\mathrm{O}$ 


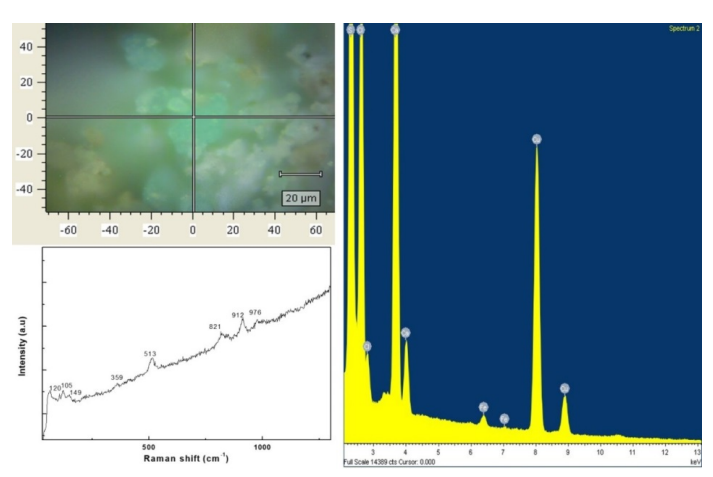

Figure 8 Green color targeted area with Raman spectra under $514 \mathrm{~nm}$ laser and its EDX spectra.

bending modes (Frost et al. 2002; Martens, Frost, Williams, 2003).

The green color pigment was observed under a scanning electron microscope and EDX data was taken, Table 1. From the EDX data, it is observed that green pigment contains about $25.73 \mathrm{wt}$. \% of copper and $8.11 \mathrm{wt}$. \% of chloride indicating use of atacamite for green. The calcium, sulfur, and oxygen presence are due to the gypsum base used for painting works. There is the occurrence of traces of iron ( 0.49 wt. \%) probably mixed for the desired hue as seen from the EDX spectra of the green pigment (Figure 8).

The WD-XRF analysis of green pigment (Table 2) shows that copper ( $\mathrm{Cu} \mathrm{K} \alpha$ line) is the majority element followed by calcium and a smaller percentage of lead and iron. The lead and iron may correspond to pigments base on iron and lead oxides that were mixed with the green pigments base to obtain the wanted hue. There is also the presence of chloride ( $8.45 \mathrm{wt}$. \%) pointing towards the use of atacamite for green color.

\subsubsection{Orange pigment}

The Orange spot was targeted under $785 \mathrm{~nm}$ laser excitation and the Raman spectra recorded (Figure 9). The most intense peaks recorded at 117 and $545 \mathrm{~cm}^{-1}$ and medium intensity peaks at 148 and $386 \mathrm{~cm}^{-1}$ correspond to red lead. There is also a weak band of red lead at 310 $\mathrm{cm}^{-1}$ seen in the spectra. In the Raman spectra of orange spot bands at 223 and $1307 \mathrm{~cm}^{-1}$ were also observed which correspond to hematite. From the Raman data,

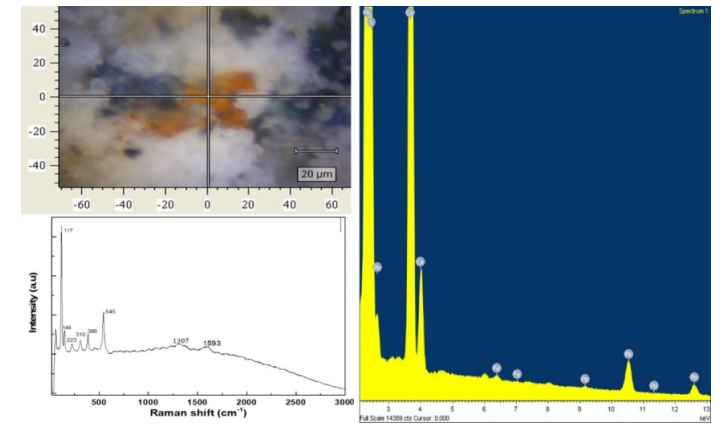

Figure 9 Orange color targeted area with Raman spectra under $785 \mathrm{~nm}$ laser and its EDX spectra.

it appears that there is mixing of some percentage of hematite in the red lead to obtain orange color. There is also a small peak at $1593 \mathrm{~cm}^{-1}$ which may be assigned to carbon black. This shows that orange color was generated by mixing red lead, red ochre, and traces of carbon black.

From the EDX data of orange pigment (Table 1), the presence of a higher percentage of lead (19.80 wt. \%) is observed along with traces of iron. The presence of $\mathrm{Ca}$, $\mathrm{S}$ and oxygen can be traced back to the gypsum base on which the color was applied. From EDX spectra of the orange pigment (Figure 8), it is observed that there is mixing of hematite in the red lead for the orange color. The WD-XRF analysis of the sample (Table 2) detects the high content of $P b$ (46.70 wt. \%) indicating the use of red lead. There is also the presence of iron detected through the WDX data pointing towards the mixing of a small percentage of hematite in the red lead to obtain the orange color.

\subsubsection{Red ochre}

Another area of the sample targeted in this study is ochre color. The ochre spot was targeted under 785 laser excitations and the Raman spectra recorded. The Raman bands of red ochre are mostly observed at 225, 290 and $405 \mathrm{~cm}^{-1}$. From the Raman spectra (Figure 10) it is observed that there is a strong band at $283 \mathrm{~cm}^{-1}$ and medium intensity band at $402 \mathrm{~cm}^{-1}$ which may be assigned to red ochre. There is a small shift in the peaks of red ochre due to the spectral resolution of the instrument.

The ochre spot was also observed under WD-XRF (Table 2). The data showed a high percentage of iron (62.9 


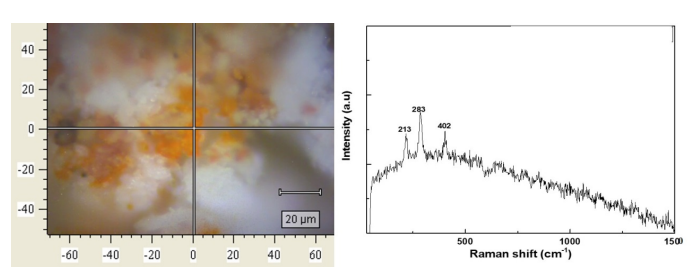

Figure 10 Red ochre color targeted area \& its Raman spectra under $785 \mathrm{~nm}$ laser.

wt. \%) along with traces of lead for intense color. The lead-in traces were probably mixed to obtain the desired hue. The red ochre color differs from the orange spot on account of the presence of iron and lead. There is a very high percentage of iron in red ochre color with traces of red lead whereas in the orange spot red lead is predominantly present in higher concentration with traces of iron added for the desired hue (Balakhnina et al. 2011; ŻmudaTrzebiatowska et al. 2015; Bikiaris et al. 2000).

\section{GC-MS analysis of the binder}

The GC-MS chromatogram of the sample is shown in Figure 11 with marked important peaks. The sample showed the occurrence of fats, oils and resinous materials. The presence of saturated and unsaturated fatty acids is typical of degraded oils as well as the use of drying oils, either as an unsaturated plant-derived oil or more saturated animal fat. The presence of long chain fatty acids with an even number of carbons (palmitic acid and stearic acid) indicated the occurrence of beeswax, however, there was no evidence about the presence of long chain linear saturated hydrocarbons with fatty acids that ruled out the occurrence of beeswax. The presence of beeswax was documented in the earthen plaster of Bezeklik as a binder (Sharma and Singh, 2019) for the sourced soil.

The possibility of unsaturated plant-derived oil could be assigned as retention peak of unsaturated fatty acids such as linolenic acid, erucic acid, and dihomo-gammalinolenic acid are showing at $x, y, z$. The source of erucic acid is found mainly in the Brassica family of plants such as canola, rapeseed, wallflower seed, mustard seed as well as Brussels sprouts and broccoli. The linolenic acid is found in Borage, also known as a starflower, is an annual herb in the flowering plant family Boraginaceae, unlike dihomo-gamma-linolenic acid found only in trace

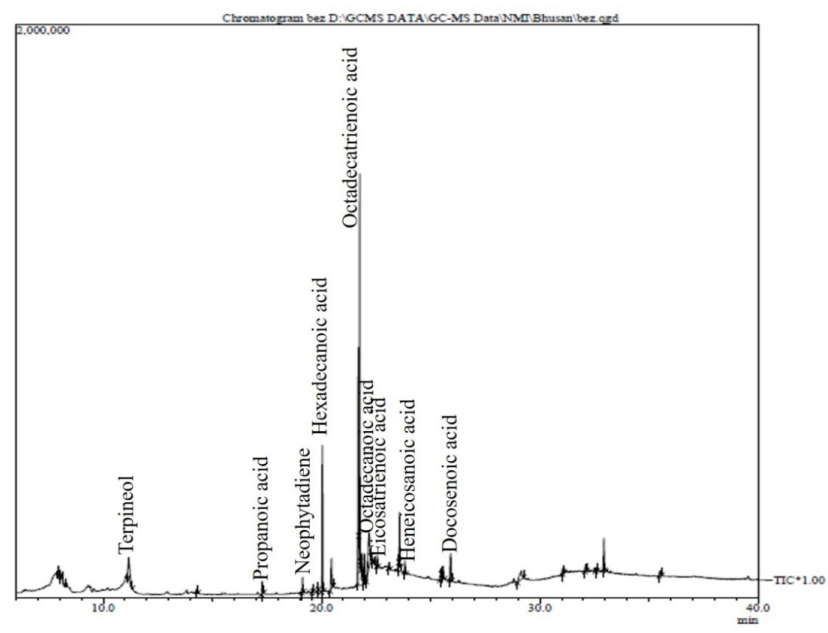

Figure 11 GC-MS chromatogram of pigment-binder of Bezeklik.

amounts in animal products.

The terpenoids are used as a general definition for the composition of resin. This is present as lower molecular weight terpenoids in two (monoterpenoids) or three (sesquiterpenoids) units. In the higher terpenoids (diand tri-terpenoids), it is present as four and six units. Di- and tri- terpenoids are not found together in a single resin source (Mills and White, 1994, 1995). The Terpineol is monoterpene alcohol which is synthesized from $\alpha$-Pinene.

It is found in the oils of many species of coniferous trees, notably the pine. Pines are considered to be the most likely source of resin from the Pinaceae family. It is always the cheapest and the most abundant resin producer (Mills and White, 1994). Neophytadiene is a member of the class of compounds known as sesquiterpenoids. Sesquiterpenoids are terpenes with three consecutive isoprene units. The presence of sesquiterpenoid resin shows the occurrence of animal origin: shellac.

\section{Conclusion}

The laboratory analysis of painted fragments of Bezeklik has demonstrated the use of gypsum, azurite, atacamite, red lead, lamp black, hematite as pigments for artworks. The results obtained through Raman spectroscopy have been also corroborated by the data obtained from WD- 
XRF and SEM-EDX. The analytical results pointed out that pigments used for Bezeklik artworks match to other Grottoes like Dunhuang situated in the vicinity (Zhang et al., 2015). However the organic binder used in Bezeklik artworks identified as fatty acids and resins through GCMS analysis differ to neighboring artworks of Kezil, Dunhuang Caves etc. where mostly animal glue have been reported as an organic binder for pigments.

\section{Acknowledgement}

The authors are highly thankful to Dr. Ravindran and Dr. Ramanathaswamy Pandian, scientists IGKAR, and Dr. Shradhanjali Sahu, Research fellow, IGKAR for the help extended for the analysis of the pigment samples. The authors are thankful to Shri Dighe Bhushan Research Scholar, National Museum Institute, New Delhi for all his help.

\section{Bibliography}

[1] Antunes, V., Candeias, A., Oliveira, M. J., Longelin, S., Serrão, V., Seruya, A. I, et al. Characterization of Gypsum and Anhydrite ground Layers in 15th and 16th centuries Portuguese Paintings by Raman Spectroscopy and other Techniques, J Raman Spectrosc, 45.11-12(2014): 1026-33.

[2] Balakhnina, I. A., Brandt, N. N., Kimberg, Y. S., Rebrikova, N. L., Chikishev, A. Y. Variations in the IR Spectra of Yellow Ochre due to Mixing with Binding Medium and Drying., J Appl Spectrosc, 78.2 (2011): 183-8.

[3] Bell, I. M., Clark, R. J. H., Gibbs, P. J. Raman spectroscopic Library of Natural and Synthetic Pigments (pre- $\approx 1850$ AD), Spectrochim Acta Part A Mol Biomol Spectrosc, 53.12 (1997): 2159-79.

[4] Best, S. P., Clark, R. J. R., Daniels, M. A. M., Porter, C. A., Withnall R. Identification by Raman Microscopy and Visible reflectance Spectroscopy of Pigments on an Icelandic Manuscript, Stud Conserv, 40.1 (1995): 31-40.

[5] Bikiaris, D., Daniilia, S., Sotiropoulou, S., Katsimbiri, O., Pavlidou, E., Moutsatsou, A. P., et al. Ochre- differentiation through micro-Raman and microFTIR Spectroscopies: Application on Wall paintings at Meteora and Mount Athos, Greece. Spectrochim Acta - Part A Mol Biomol Spectrosc, 56.1 (2000): 318.

[6] Burgio, L., Clark, R. J. H., Rosser-Owen M. Raman Analysis of Ninth-century Iraqi Stuccoes from Samarra, J Archaeol Sci, 34.5 (2007): 756-62.

[7] Burgio, L., Clark, R. J. H. Library of FT-Raman spectra of Pigments, minerals, Pigment media and Varnishes, and Supplement to existing Library of Raman Spectra of Pigments with visible Excitation, Spectrochim Acta Part A Mol Biomol Spectrosc, 57.7(2001): 1491-521.

[8] Burrafato, G., Calabrese, M., Cosentino, A., Gueli, A. M., Troja, S. O., Zuccarello, A. Colo Raman Project: Raman and Fluorescence Spectroscopy of Oil, Tempera and Fresco paint Pigments, J Raman Spectrosc, 35.10 (2004): 879-86.

[9] Caggiani, M. C., Cosentino, A., Mangone, A. Pigments Checker version 3.0, A Handy set for Conservation Scientists: A free online Raman Spectra Database, Microchem J, 129 (2016): 123-32.

[10] Cennini, C. Il libro dell'arte, a cura di F. Frezzato, Neri Pozza Ed Vicenza, 2003.

[11] Clark, R. J. H., Curri, M. L. The Identification by Raman Microscopy and X-ray Diffraction of Iron-oxide pigments and of the Red pigments found on Italian Pottery Fragments, J Mol Struct, 440.1 (1998): 10511.

[12] Clark, R. J. H. Raman Microscopy as a Structural and Analytical Tool in the Fields of Art and Archaeology, J Mol Struct, 834-836 (2007): 74-80.

[13] Coccato, A., Jehlicka, J., Moens, L., Vandenabeele, P. Raman Spectroscopy for the Investigation of Carbon-based Black Pigments, J Raman Spectrosc, 46. 10 (2015): 1003-15.

[14] Colomban, P. Lapis Lazuli as unexpected Blue Pigment in Iranian Lâjvardina Ceramics, J Raman Spectrosc, 34.6 (2003): 420-3. 
[15] Correia, A. M., Clark, R. J. H., Ribeiro, M. I. M., Duarte, M. L. T. S. Pigment study by Raman Microscopy of Twenty three Paintings by the Portuguese Artist Henrique Pousão (1859-1884), J Raman Spectrosc, 38.11 (2007): 1390-405.

[16] Coupry, C., Lautié, A., Revault, M., Dufilho, J. Contribution of Raman Spectroscopy to Art and History, J Raman Spectrosc, 25.1 (1994): 89-94.

[17] David, A. R., Edwards, H. G. M., Farwell, D. W., Faria D. L. A De. Raman Spectroscopic Analysis of Ancient Egyptian Pigments, Archaeometry, 43.4 (2003): 461-73.

[18] Dighe, B., Singh, M., Mani, B. R., and Sahay, Binoy. Oryza sativa L. (Rice) in the Ancient Earthen Plasters of Painted Fragments from Bezeklik, China, Studies in Conservation, 64:5, (2019): 273-283.

[19] Edwards, H. G. M., Middleton, P. S., Villar, S. E. J., de Faria, D. L. A. Romano-British Wall-paintings II: Raman Spectroscopic Analysis of two Villa sites at Nether Heyford, Northants, Anal Chim Acta, 484.2 (2003): 211-21.

[20] Ellen, E., Simon, S. The graying phenomenon on mural paintings from Cave 8, Kizil, Xinjiang, China. Proceedings of International Conference on the Research and Conservation of the Kucha Caves, Kucha, 7-11th August 2011, Kucha Research Academy, 2015.

[21] Ernst, R. R. In situ Raman Microscopy applied to Large Central Asian Paintings, J Raman Spectrosc, 41.3(2010): 275-84.

[22] Frausto-Reyes, C., Ortiz-Morales M., BujdudPérez, J. M., Magaña-Cota, G. E., Mejía-Falcón R. Raman Spectroscopy for the Identification of Pigments and Color measurement in Dugès Watercolors, Spectrochim Acta Part A Mol Biomol Spectrosc, 74.5 (2009): 1275-9.

[23] Frost, R. L., Martens, W. N., Rintoul, L., Mahmutagic, E., Kloprogge, J. T. Raman Spectroscopic study of Azurite and Malachite at 298 and 77 K, J Raman Spectrosc, 33.4 (2002): 252-9.
[24] Frost, R. L., Martens, W., Kloprogge, J. T., Williams, P. A. Raman Spectroscopy of the Basic Copper chloride Minerals Atacamite and Paratacamite: Implications for the Study of Copper, Brass and Bronze objects of Archaeological Significance, J Raman Spectrosc, 3.10 (2002): 801-6.

[25] Jehlička J., Vítek P., Edwards H. G. M., Hargreaves M. D., Čapoun T. Fast detection of sulphate minerals (gypsum, anglesite, baryte) by a portable Raman Spectrometer, J Raman Spectrosc, 40.8 (2009): 1082-6.

[26] Marszałek, M. Identification of Secondary Salts and their Sources in deteriorated Stone Monuments using Micro-Raman Spectroscopy, SEM-EDS and XRD, J Raman Spectrosc, 47.12 (2016): 1473-85.

[27] Mattei, E., de Vivo G., Santis, A De., Gaetani, C., Pelosi, C., Santamaria, U. Raman Spectroscopic Analysis of Azurite Blackening, J Raman Spectrosc, 39.2 (2008): 302-6.

[28] Mazzeo, R., Joseph, E., Prati, S., Ma, T., Gautier, G., van Valen L. M. Scientific Examination of the Traditional Materials and Techniques used in Yuan dynasty Wall paintings, In: Conservation of Ancient sites on the Silk Road: Proceedings of the second International Conference on the Conservation of Grotto Sites, Mogao Grottoes, Dunhuang, People's Republic of China, June 28-July 3, 2004, Getty Conservation Institute., Los Angeles, 2010.

[29] Mills, J. S., White, R. Organic Chemistry of Museum Objects, BH Series, Conservation and Museology, Oxford, 1994.

[30] Mora, P., Mora, L., Philippot, P. Conservation of Wall Paintings, Butterworths, 1984.

[31] Naumova, M. M, Pisareva, S. A. A Note on the Use of Blue and green Copper Compounds in Paintings, Stud Conserv, 39.4 (1994):277-83.

[32] Pérez-Alonso, M., Castro, K., Madariaga, J. M. Investigation of Degradation Mechanisms by Portable Raman Spectroscopy and Thermodynamic Speciation: The Wall painting of Santa María de Lemoniz (Basque Country, North of Spain), Anal Chim Acta, 571.1(2006): 121-8. 
[33] Prieto-Taboada, N., Gómez-Laserna, O., MartínezArkarazo, I., Olazabal, M. Á., Madariaga, J. M. Raman Spectra of the Different Phases in the $\mathrm{CaSO}_{4}$ $\mathrm{H}_{2} \mathrm{O}$ System, Anal Chem, 86.20 (2014): 10131-7.

[34] Ravindran, T. R., Arora, A. K., Ramya, S., Rao, R. V. S., Raj, B. Raman Spectroscopic study of Medieval Indian Art of 17th Century, $J$ Raman Spectrosc, 42.4 (2010): 803-7.

[35] Ravindran, T. R., Arora, A. K., Singh, M., Ota, S. B. On-and off-site Raman study of Rock-shelter Paintings at World-heritage Site of Bhimbetka, J Raman Spectrosc, 44.1 (2012): 108-13.

[36] Schmidt, B. A., Ziemann, M. A., Pentzien, S., Gabsch, T., Koch, W., Krüger, J. Technical Analysis of a Central Asian wall Painting detached from a Buddhist cave Temple on the Northern Silk Road, Stud Conserv, 61.2 (2016): 113-22.

[37] Sharma, R. K. Painting Technique and Materials of Cave Mural Paintings in India and their Conservation Problem, In: The Mural Painting on Silk Route, 29th Annual International Symposium of Cultural Propert, Tokyo, 2007.

[38] Sharma, A., and Singh, M.R. Multi-analytical Investigation of the Composition and Binders Used in the Earthen Support Layer of Fifth-Fourteenth Century CE Painted Fragments From Bezeklik, China, Studies in Conservation. (2019): 1-17.

[39] Singh, M. Microclimatic Condition in Relation to Conservation of Cave no-2 Murals of Ajanta, Curr Sci., 101.1 (2011): 89-94.

[40] Smith, G. D., Clark, R. J. H. The Role of $\mathrm{H}_{2} \mathrm{~S}$ in Pigment Blackening, J Cult Herit, 3.2 (2002): 101-105.

[41] Sturman, L. Some Problems in Analysis of aged Organic Materials in Art works and Artefacts, ICCM Bull., 6.2 (1980): 53-60.

[42] Tomasini, E. P., Halac, E. B., Reinoso, M., Liscia, E. J Di., Maier, M. S. Micro-Raman Spectroscopy of Carbon-based Black Pigments, J Raman Spectrosc, 43.11 (2012): 1671-1765.
[43] van der Weerd, J., Smith, G. D., Firth, S., Clark, R. J. H. Identification of Black Pigments on Prehistoric Southwest American potsherds by Infrared and Raman microscopy, J Archaeol Sci, 31.10 (2004): 1429-1437.

[44] Veiga, A., Mirão, J., Candeias, A. J., Rodrigues, P. S., Teixeira, D. M., Muralha, V. S. F, et al. Pigment Analysis of Portuguese Portrait Miniatures of 17th and 18th Centuries by Raman Microscopy and SEM-EDS, J Raman Spectrosc, 45.10 (2014): 947957.

[45] Wainwright, I. N. M., Ian, N. M., Moffatt, E. A., Sirois, P. J., Young, G. S. Analysis of Wall Painting Fragments from the Mogao and the Bingling Temple Grottoes. In: Agnew N (Ed.), Conservation of Ancient Sites on the Silk Road: Proceedings of the Second International Conference on the Conservation of Grotto Sites, Mogao Grottoes, Dunhuang, People's Republic of China, June 28-July 3, 2004.: Getty Conservation Institute., Los Angeles 1997.

[46] Wang, F. Geo-Architecture and Landscape in China's Geographic and Historic Context [Internet], Springer Singapore Singapore, 2016. http://link.springer.com/10.1007/978-981-10-04834

[47] Zhang, Y., Wang, J., Liu, H., Wang, X., Zhang, S. Integrated Analysis of Pigments on Murals and Sculptures in Mogao Grottoes, Anal Lett, 48.15 (2015): 2400-2413.

[48] Żmuda-Trzebiatowska, I., Wachowiak, M., Klisińska-Kopacz, A., Trykowski, G., "liwiński, G. Raman Spectroscopic Signatures of the Yellow and Ochre paints from Artist Palette of J. Matejko (1838-1893), Spectrochim Acta - Part A Mol Biomol Spectrosc, 136. PB (2015): 793-801.

[49] Zuixiong L. Deterioration and Treatment of Wall Paintings in Grottoes along the Silk Road in China and Related Conservation Effects. In: Agnew N, (Ed.), Conservation of Ancient Sites on the Silk Road: Proceedings of an International Conference on the Conservation of Grotto Sites GCI Proceedings, People's Republic of China, June 28-July 3, 2004, Getty 
Conservation Institute., Los Angeles, 2010, pp. 4655.

[50] Zumbuehl, S., Scherrer, N. C., Berger, A., Eggenberger, U. Early Viridian Pigment Composition Characterization of a (hydrated) Chromium Oxide Borate Pigment, Stud Conserv, 54.3 (2009): 149-159.

[51] Zuo, J., Zhao, X., Wu, R., Du, G., Xu, C., Wang, C. Analysis of the Pigments on Painted Pottery Figurines from the Han Dynasty's Yangling Tombs by Raman Microscopy, J Raman Spectrosc, 34.2 (2003): 121-125. 